\title{
Corporate Entrepreneurship and Agency Cost: A Theoretical Perspective
}

\author{
Syed Zulfiqar Ali Shah, Nousheen Tariq Bhutta \\ Faculty of Management Sciences, International Islamic University, Islamabad, Pakistan \\ Email: zulfiqar.shah@gmail.com,imaantariq@gmail.com
}

Received November 1, 2012; revised December 12, 2012; accepted January 8, 2013

Copyright (C) 2013 Syed Zulfiqar Ali Shah, Nousheen Tariq Bhutta. This is an open access article distributed under the Creative Commons Attribution License, which permits unrestricted use, distribution, and reproduction in any medium, provided the original work is properly cited.

\begin{abstract}
The study aims to fill the gap in literature by ascertaining the link between corporate entrepreneurship and agency cost. It presents conceptual framework between corporate entrepreneurship and agency cost, on the basis of their theoretical background. Being a prelude endeavour, it provides a keystone for future studies.
\end{abstract}

Keywords: Corporate Entrepreneurship; Agency Cost; Relationship between Corporate Entrepreneurship; Agency Cost

\section{Introduction}

In recent years, the research on corporate entrepreneurship has promoted rapidly, and it has been depicted that corporate entrepreneurship reflects the development and implementation of new ideas in organization [1] and it might be a vital element of successful organizations [2]. Corporate entrepreneurship can enhance the shareholder's value by creating the work environment that boosts the individual and corporate growth, presenting employees an opportunity to utilize their creative skills and formulating the organizational culture that enhance the market performance of firm [3]. But sometimes the executives want to maximize their share irrespective of principals that lead to agency problems arising between the shareholders and executives [4]. Firms having high agency costs are expected to face the threats from other firms in a competitive environment [5].

This study highlights the gap in literature by ascertaining relation between two well researched concepts; i.e. corporate entrepreneurship and agency cost. Although wide research on corporate entrepreneurship [6-11] and agency cost [12-16] presents up to the limited knowledge \& understanding of author, the link between corporate entrepreneurship and agency cost remains unexplored. So the speciality of this study is to explore the relationship between corporate entrepreneurship and agency cost.

\footnotetext{
*I, Nousheen Tariq Bhutta, dedicate this paper to my respectable teacher Dr. Syed Zulfiqar Ali Shah for his valuable guidance and support throughout my dissertation.
}

This study addresses a research question, given here below.

- What would be the possible relation between corporate entrepreneurship and agency cost?

This paper is organized in a way that the first section depicts the introduction of the study followed by a literature review to construct theoretical framework. After that, the last section discusses the managerial implications and future research direction.

\section{Literature Review}

\subsection{Corporate Entrepreneurship}

The notion of corporate entrepreneurship was coined by [6]. Corporate entrepreneurship, also presented as an "intrapreneurship" [6,17], corporate venturing [18] and internal corporate entrepreneurship [19]. Many scholars defined corporate entrepreneurship as "a process by which individuals inside organizations pursue opportunities independent of the resources they currently control" [20]; "a procedure whereby an individual or a group of individuals, in association with an existing organization, create a new-fangled organization or initiate renewal or innovation within that organization" [10]; "a spirit of entrepreneurship within the existing organization" [21]. Other definitions of corporate entrepreneurship by research scholars are given in Table 1, quoted by [22-25].

While reviewing the different definitions of corporate entrepreneurship, it has been found that some authors used the same terminologies for highlighting different 
concepts, whereas some researchers used different terminologies for emphasizing the same concept. Some ideas relating to corporate entrepreneurship are inferred from the above Table 1; those it confers the key conceptualization of corporate entrepreneurship are followed by:

- Strategic renewal of firm and its structure \& culture.

- Bringing novelty within the existing business.

Corporate entrepreneurship has become a crucial area of management research for the last three decades as an efficient technique for firms that operate in hostile environment [8]. The changing nature of hospitality organization can be achieved by using the lens of corporate entrepreneurship, rather than organizational structure [26]. He also explained particular steps that firms can take to promote innovation in existing environment. The firms are positively related to an entrepreneurial strategic stance, an organic structure, a competitive contour revealing a long-term orientation, high product prices and a concern for predicting industry trends in hostile environment [27].

Many research scholars confirmed that corporate ent- repreneurship has a multidimensional structure i.e. Risktaking, Innovativeness, Proactiveness and Competitive Aggressiveness [9,11]. Risk-taking as an ability of organization to avail risky projects along with high expected return; innovativeness as an ability of organization to engage in new business [28]; Proactiveness as aptitude of organization to lead in quest of opportunities; Competitive Aggressiveness as an ability of organization to compete with its competitors to attain high market share [9].

\section{Corporate Entrepreneurship (CE) Conceptual Models}

Existing theories and models of corporate entrepreneurship highlight the collaboration between entrepreneurial's personality and organizational environment [29]. Some models of corporate entrepreneurship are presented below.

\subsection{Model of Guth and Ginsberg (1990)}

Figure 1 depicts the model of [30]. They developed the

Table 1. Definitions of corporate entrepreneurship.

Definitions of Corporate Entrepreneurship

Schollhammer (1982)

Burgelman (1984)

Pinchot (1985)

Jennings \& Lumpkin (1989)

Covin \& Slevin (1989)

Guth \& Ginsberg (1990)

Covin \& Slevin (1991)

Jones \& Butler (1992)

Zahra (1995, 1996)

Chung \& Gibbons (1997)

Antoncic \& Hisrich (2003)

Kuratko, Ireland, Covin, \& Hornsby (2005)
"Internal (or intra-corporate) entrepreneurship refers to all formalized entrepreneurial activities within existing business organizations. Formalized internal entrepreneurial activities are those which receive explicit organizational sanction and resource commitment for the purpose of innovative corporate endeavours - new product developments, product improvements, new methods or procedures (p. 211)"

"Corporate entrepreneurship as extending the firm's domain of competence and corresponding opportunity set through internally generated new resource combinations"

"Intrapreneurs are 'dreamers who do', those individuals who take hands-on responsibility for creating innovation of any kind within an organization. They may be the creators or inventors but are always the dreamers who figure out how to turn an idea into a profitable reality (p. ix)”.

"Corporate entrepreneurship is defined as the extent to which new products and/or new markets are developed. An organization is entrepreneurial if it develops a higher than average number of new products and/or new markets (p. 489)"

"Corporate entrepreneurship encourages leaders to promote innovativeness, pro-activeness and risk taking among the members within a larger organizational context”

"Corporate entrepreneurship encompasses two types of phenomena and the processes surrounding them; 1) the birth of new businesses within existing organizations, i.e., internal innovations or venturing and 2) the transformation of organizations through renewal of the key ideas on which they are built, i.e. strategic renewal (p. 5)"

"Corporate entrepreneurship involves extending the firm's domain of competence and corresponding opportunity set through internally generated new resource combinations (p. 7)”

“Internal corporate entrepreneurship refers to entrepreneurial behaviour within one firm (p. 734)”

"Corporate entrepreneurship is seen as the sum of a company's innovation, renewal, and venturing efforts. Innovation involves creating and introducing products, production processes and organizational systems. Renewal means revitalizing the company's operations by changing the scope of its business, its competitive approaches or both. It also means building or acquiring new capabilities and then creatively leveraging them to add value for shareholders venturing means that the firm will enter new businesses by expanding operations in existing or new markets (1995, p. 227; 1996 p. 1715)"

"Corporate entrepreneurship is an organizational process for transforming individual ideas into collective actions through the management of uncertainties (p. 14)”

"Entrepreneurship within an existing organization, including emergent behavioural intentions and behaviours of an organization related to departures from the customary”

"Corporate entrepreneurship represents a set of behaviors "requiring organizational sanctions and resource commitments for the purpose of developing different types of value-creating innovations" (p. 700)” 
conceptual model of corporate entrepreneurship. They hypothesized that corporate entrepreneurship comprises of two phenomena; primarily "the birth of new businesses within existing organization" and secondly "the transformation of organization through renewal”. [30]'s model identifies the environment, strategic leadership, organizational form and organizational performance as antecedents of corporate entrepreneurship, while the outcomes of corporate entrepreneurship are innovation/ venturing and strategic renewal.

\subsection{Model of Covin and Slevin (1991)}

Figure 2 depicts the model of [31]. The model of [31] focuses on entrepreneurial orientation. It also demonstrates the connection between company's entrepreneurial posture and its three factors, namely external environment, strategic variables, internal variables and organizational performance. According to this model, entrepreneurial orientation leads to external environment, strategic variables and internal variables even with a weaker extent, but it shows a strong relationship with organizational performance.

\subsection{Model of Zahra (1993)}

Figure 3 depicts the model of [31]. [32] revised the model of [31] as she clearly categorized the external en-

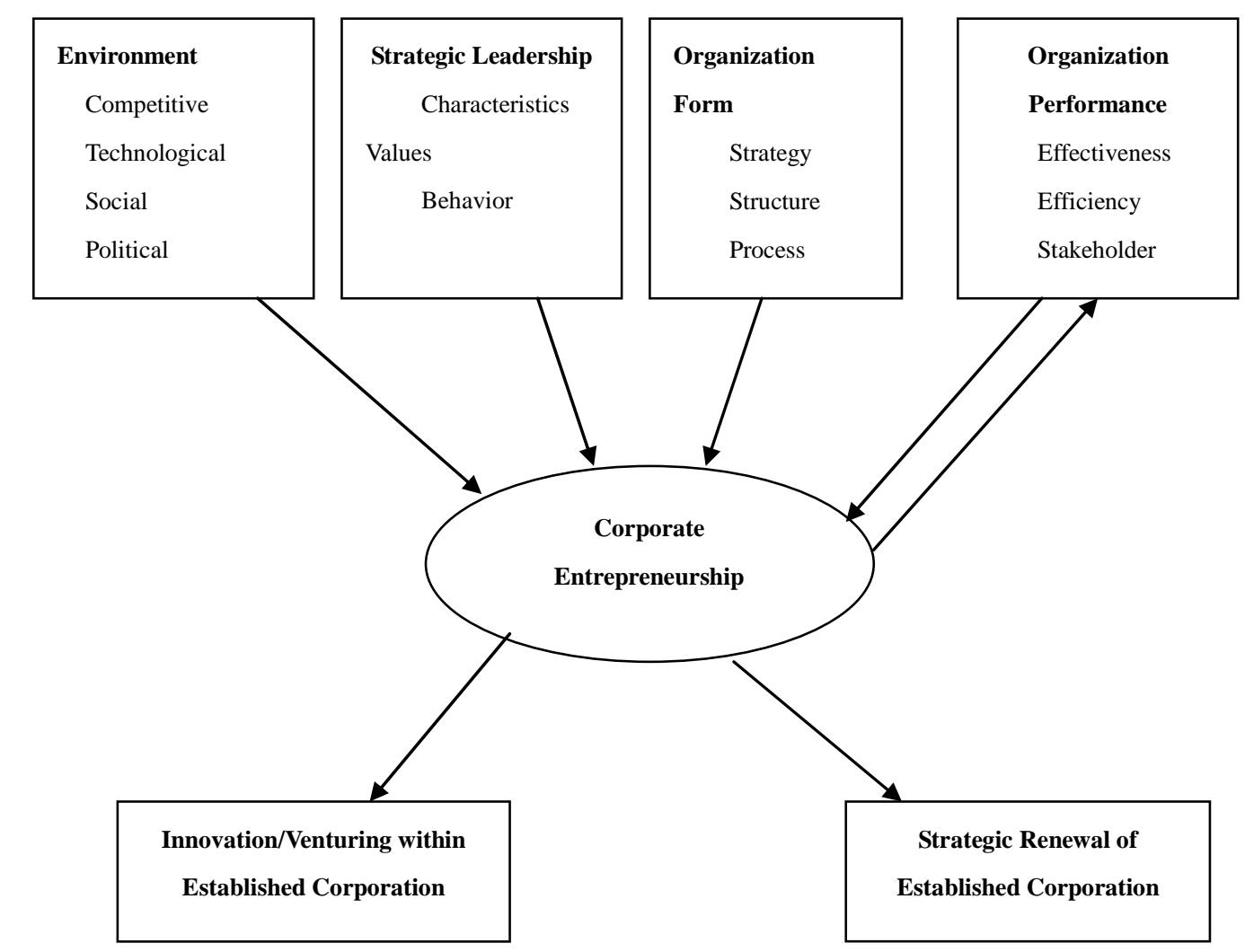

Figure 1. A strategic management perspective model of CE by Guth and Ginsberg (1990). vironmental factors and amalgamated the technological sophistication factor with dynamism factor. He included a new factor "munificence" which transpired opportunity seeking for making innovations in the industry. Furthermore, he highlighted to deem the entrepreneurial activities both at domestic and international level. The model of [31] incorporated the feedback loop between different line [22].

\subsection{Model of Lumpkin and Dess (1996)}

Figure 4 shows the model of [9]. They presented a diverse model of corporate entrepreneurship which defined the entrepreneurial orientation into five dimensions, namely risk taking, innovativeness, proactiveness, competitive aggressiveness and autonomy. They discussed that entrepreneurial orientation concerns the processes, practices and decision-making tasks that escort to entering into new market along with new products and services. According to this model, a new entry conceives a key concept of corporate entrepreneurship [22].

\subsection{Model of Barrett and Weinstein (1998)}

Figure 5 shows the model of [33]. They developed relationships between corporate entrepreneurship, market orientation, flexibility and firm performance in their "corporate entrepreneurship, flexibility and market ori- 


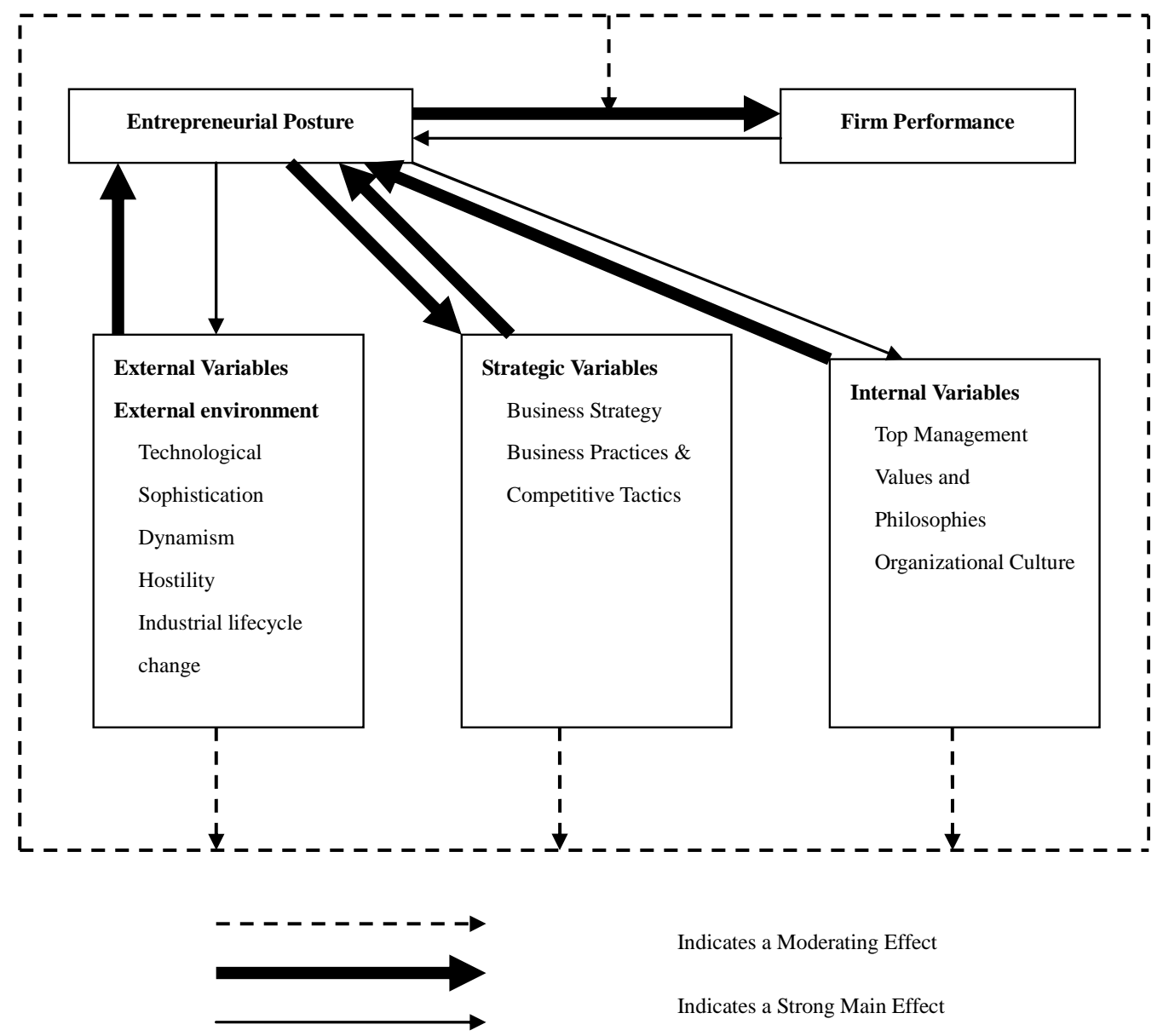

Figure 2. The Covin and Slevin (1991) model for corporate entrepreneurship.

entation (CEFMO)” model, endeavoring to elucidate the organizational mission strategy.

\subsection{Model of Goosen, De Coning and Smit (2002)}

Figure 6 shows the model of [34]. They incorporated three well researched elements of corporate entrepreneurship, namely innovativeness, self renewal and proactiveness.

This model presents some additional dimensions of corporate entrepreneurship, namely market orientation, managerial styles, organizational structure, strategy and environment, innovativeness, risk taking, proactiveness that enhance the organizational culture [22].

In this model Y (1) is the level of corporate entrepreneurship and I (1) is innovativeness component, $M$ (1) is management component and $\mathrm{P}(1)$ is proactiveness component.

\subsection{Public Sector Corporate Entrepreneurship Model (2007)}

Figure 7 shows the model of [24] that can be applied to public sector organizations. In this model, they incorporated corporate entrepreneurship and its two antecedents', namely public sector organization and external environment.

This model presents the dimensions of public sector organization (Structure/formalization, decision-making/ control, rewards/motivation, culture, risk taking and proactiveness) and external environment (political, complexity, munificence and change) that can influence the organization to employ the corporate entrepreneurial task.

\section{Agency Cost}

Currently, agency problems are rapidly emerging in the modern organizations [35] and are referred to as particular case in the current theory of firm [12]. It also proposed that ownership and managerial interest may not be linked, that leads to agency costs [12]. The model of agency costs, first presented by [12], as “Agency costs as the sum of three variables: 1 ) the monitoring expenditures of the principle, 2) the bonding expenditures by the agent, and 3) the residual loss".

Agency cost can be apparent in various kinds contain- 


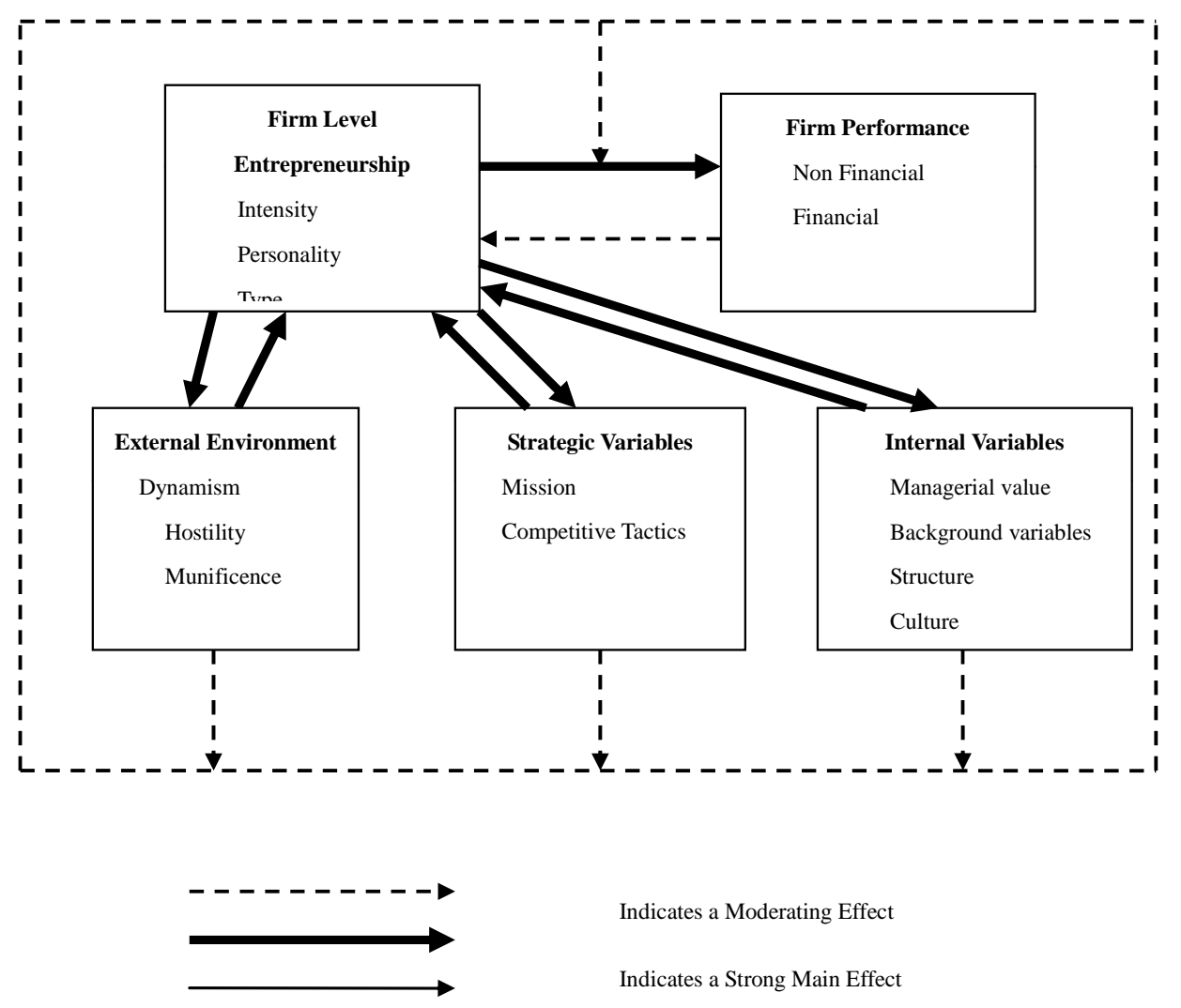

Figure 3. The zahra (1993) model for corporate entrepreneurship.

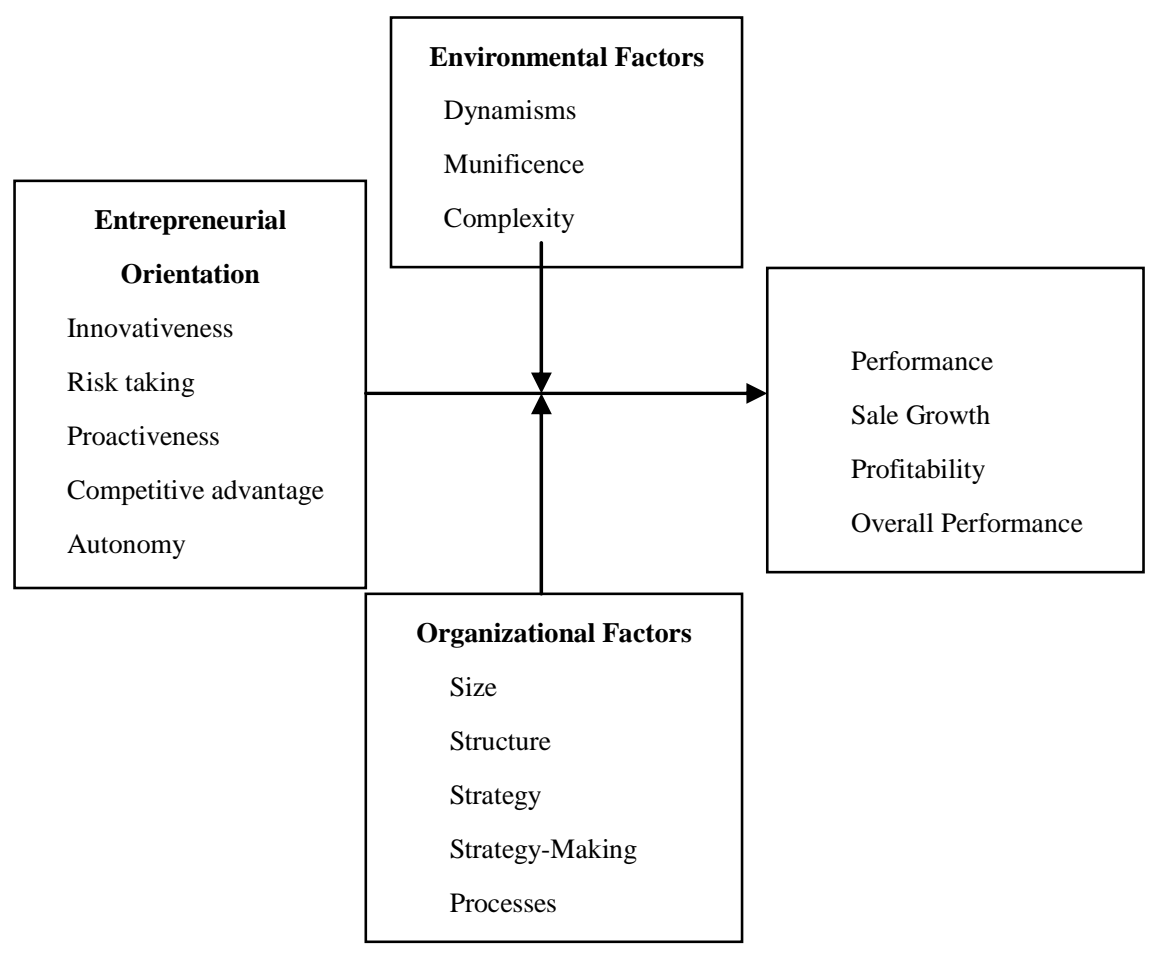

Figure 4. The Lumpkin and Dess (1996) model for corporate entrepreneurship.

ing self interest behaviors of managers usually concerned on rank, excessive profit consumption, wrong de- cision making regarding investment and firm, misallocation of resources and accounting practices; agency cost 


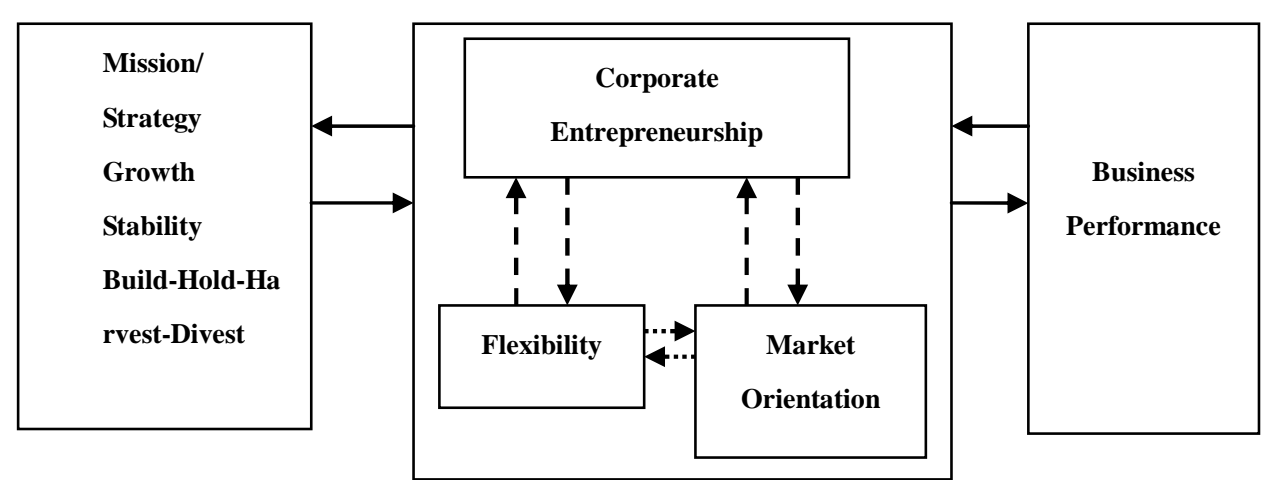

Figure 5. The CEFMO model of Barrett and Weinstein (1998).

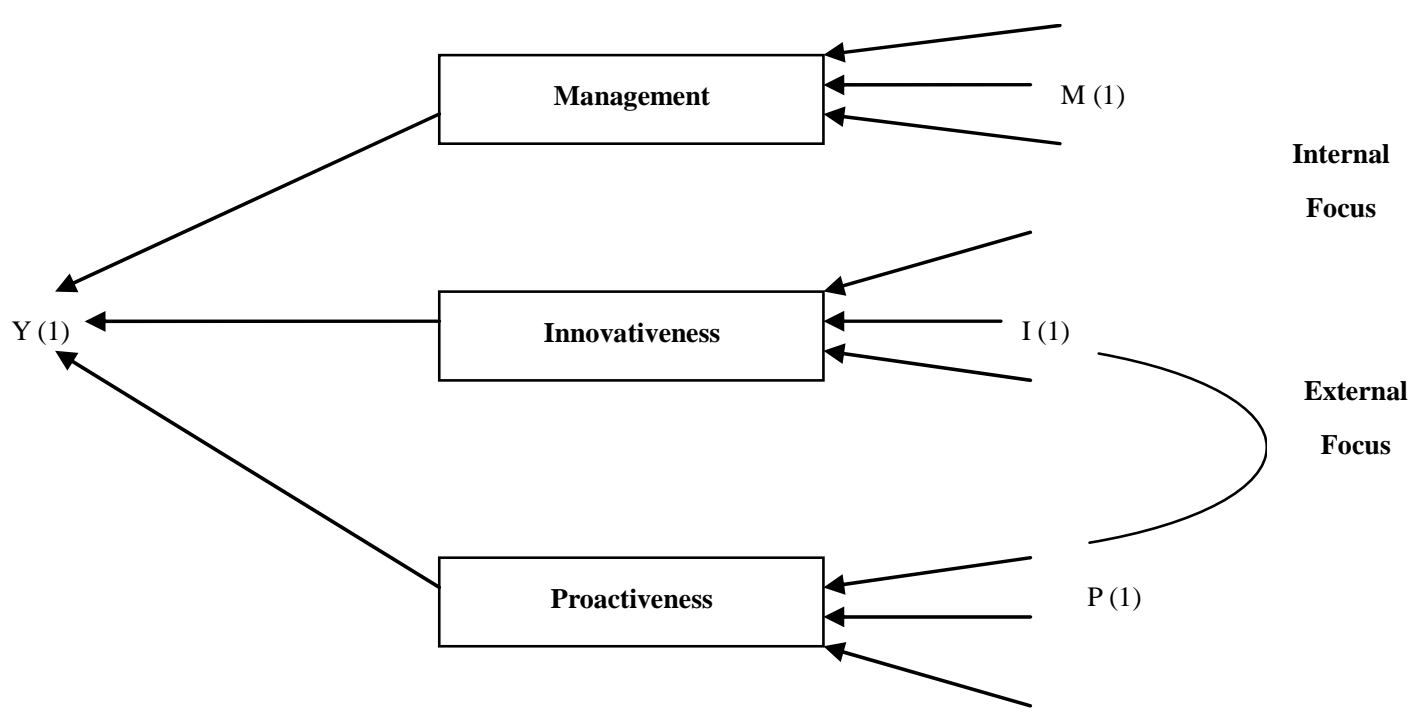

Figure 6. The model of model of goosen, de coning and smit (2002).

affects the shareholder's wealth as well as other stakeholders' wealth like debt financers, employee society [35].

\section{Relationship between Corporate Entrepreneurship and Agency Cost}

A better consideration of the association between corporate entrepreneurship and agency cost is imperative for many reasons. Firstly, corporate entrepreneurship has significant positive to firm performance $[8,31,36]$. However, agency cost has significantly negative to firm performance $[16,37,38]$. They both inversely influence firm performance. Secondly, corporate entrepreneurship is a strategic track in achieving the competitive position in a global environment $[7,8]$. On one hand, qualified inside directors can assess the worth of corporate entrepreneurship tasks more consistently [39]. Thirdly, agency theory also escorts to hypothesize that in the competitive milieu generally companies having high levels of agency cost are apt to face threats from their rival com- panies [5]. However, through efficient competition the agency cost can be minimized while increasing the managerial efficiency that would lead to market performance benefits, in the form of increased valuation [40]. From that it can be supposed that high agency cost discourages the competitive advantage which leads to lower corporate entrepreneurship. It infers that competitive advantage reduces the agency cost that leads to high corporate entrepreneurship. This appears that nexus between corporate entrepreneurship and agency cost may be bi-directional in nature. For further justification the relationship between agency costs and the dimensions of corporate entrepreneurship were explored.

\section{Conclusion and Research Implications}

The novel feature of this study is to bridge a gap between corporate entrepreneurship and agency cost. Being a first endeavor to gain the notice of academicians and practitioners towards this oversight in literature by collaborating the corporate entrepreneurship and agency cost, this 


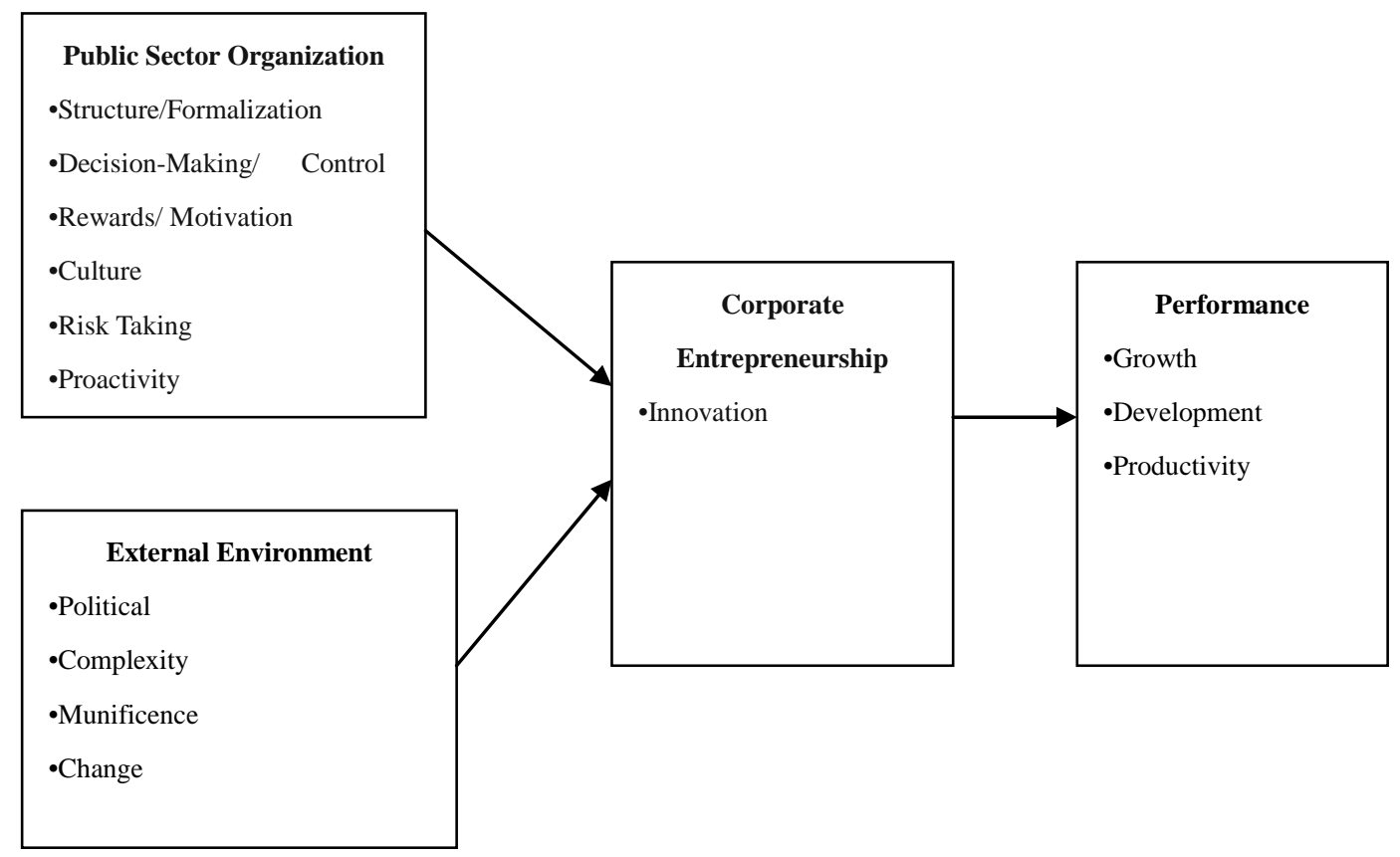

Figure 7. Model of public sector corporate entrepreneurship (2007).

study provides a keystone for future studies. Entrepreneurs bring innovative ideas into organizations while incorporating corporate entrepreneurship. Entrepreneurs actively contribute to strategic orientation process. They do not depend upon manager's actions for value creation that reduces managerial self interest. Ultimately, this theoretical relationship would be empirically tested at home or abroad in future studies

\section{REFERENCES}

[1] J. S. Hornsby, D. F. Kuratko and S. A. Zahra, "Middle Managers' Perception of the Internal Environment for Corporate Entrepreneurship: Assessing a Measurement Scale," Journal of Business Venturing, Vol. 17, No. 3, 2002, pp. 253-273. doi:10.1016/S0883-9026(00)00059-8

[2] R. M. Kanter, "The Change Masters,” Touchstone, Simon \& Schuster, New York, 1984.

[3] S. A. Zahra, "Predictors and Financial Outcomes of Corporate Entrepreneurship: An Exploratory Study,” Journal of Business Venturing, Vol. 6, No. 4, 1991, pp. 259-285. doi:10.1016/0883-9026(91)90019-A

[4] A. Barnea, R. A. Haugea and L. W. Senbet, "Agency Problems and Financial Contracting Englewood Cliffs,” Prentice-Hall, Upper Saddle River, 1985.

[5] M. C. Jensen and R. S. Ruback, "The Market for Corporate Control,” Journal of Financial Economics, Vol. 11, No. 1, 1983, pp. 5-49. doi:10.1016/0304-405X(83)90004-1

[6] G. Pinchot III, "Intrapreneuring: Why You Don't Have to Leave the Corporation to Become an Entrepreneur," Harper \& Row, New York, 1985.
[7] P. Drucker, “The Discipline of the Innovator," Harvard Business Review, Vol. 63, No. 3, 1985, pp. 67-72.

[8] S. A. Zahra and J. Covin, "Contextual Influences on the Corporate Entrepreneurship-Company Performance Relationship in Established Firms: A Longitudinal Analysis,” Journal of Business Venturing, Vol. 10, No. 1, 1995, pp. 43-58.

[9] G. T. Lumpkin and G. G. Dess, "Clarifying the Entrepreneurial Orientation Construct and linking it to Performance," Academy of Management Review, Vol. 21, No. 1, 1996, pp. 135-172.

[10] P. Sharma and J. J. Chrisman, “Toward a Reconciliation of the Definitional Issues in the Field of Corporate Entrepreneurship,” Entrepreneurship Theory and Practice, Vol. 23, No. 3, 1999, pp. 11-27.

[11] G. G. Dess, R. D. Ireland, S. A. Zahra, S. W. Floyd, J. J. Janney and P. J. Lane, "Emerging Issues in Corporate Entrepreneurship,” Journal of Management, Vol. 29, No. 3, 2003, pp. 351-378.

[12] M. C. Jensen and W. H. Meckling, "Theory of the Firm: Managerial Behavior, Agency Costs and Ownership Structure,” Journal of Financial Economics, Vol. 3, No. 4, 1976, pp. 305-360. doi:10.1016/0304-405X(76)90026-X

[13] M. C. Jensen, “Agency Costs of Free Cash Flow, Corporate Finance, and Takeovers," The American Economic Review, Vol. 76, No. 2, 1986, pp. 323-332.

[14] M. C. Jensen, “The Modern Industrial Revolution, Exit, and the Failure of Internal Control Systems," Journal of Finance, Vol. 48, No. 3, 1993, pp. 831-880. doi:10.1111/j.1540-6261.1993.tb04022.x

[15] J. S. Ang, R. A. Cole and J. W. Lin, "Agency Costs and Ownership Structure,” Journal of Finance, Vol. 55, No. 1, 2000, pp. 81-106. doi:10.1111/0022-1082.00201 
[16] S. Xiao, "How Do Agency Costs Affect Firm Performance? Evidence from China," Furman University, Greenville, 2008, pp. 1-25.

[17] B. Antoncic and R. D. Hisrich, "Intrapreneurship: Construct Refinement and Cross-Cultural Validation," Journal of Business Venturing, Vol. 16, No. 5, 2001, pp. 495527. doi:10.1016/S0883-9026(99)00054-3

[18] K. Vesper, “New Venture Strategies,” Englewood Cliffs, Prentice-Hall, New York, 1990.

[19] G. R. Jones and J. E. Butler, "Managing Internal Corporate Entrepreneurship: An Agency Theory Perspective," Journal of Management, Vol. 18, No. 4, 1992, pp. 733749. doi:10.1177/014920639201800408

[20] H. H. Stevenson and J. C. Jarillo, “A Paradigm of Entrepreneurship: Entrepreneurial Management,” Strategic Management Journal, Vol. 11, 1990, pp. 17-27.

[21] R. D. Hisrich and M. P. Peters, "Entrepreneurship: Starting, Developing and Managing a New Enterprise,” 7th Edition, Irwin, Chicago, 2007.

[22] M. Adonisi, “The Relationship between Corporate Entrepreneurship, Market Orientation, Organizational Flexibility and Job Satisfaction,” University of Pretoria, Pretoria, 2003, pp. 1-171.

[23] T. M. Davis, "Corporate Entrepreneurship Assessment Instrument: Systematic Validation of A Measure," Graduate School of Engineering and Management, Air University, 2006, pp. 1-88.

[24] C. Kearney, R. Hisrich and F. Roche, "A Conceptual Model of Public Sector Corporate Entrepreneurship," International Entrepreneurship and Management Journal ,Vol. 4, No. 3, 2007, pp. 295-313.

[25] B. Antoncic and I. Prodan, “Alliances, Corporate Technological Entrepreneurship and Firm Performance: Testing a Model on Manufacturing Firms,” Technovation, Vol. 28, No. 5, 2008, pp. 257-265. doi:10.1016/j.technovation.2007.07.005

[26] L. Pittaway, “Corporate Enterprise: A New Reality for Hospitality Organizations?” Hospitality Management, Vol. 20, No. 4, 2001, pp. 379-393. doi:10.1016/S0278-4319(01)00023-8

[27] J. G. Covin and D. P. Slevin, "Strategic Management of Small Firms in Hostile and Benign Environments," Strategic Management Journal, Vol. 10, No. 1, 1989, pp. 7587. doi:10.1002/smj.4250100107

[28] D. Miller, "The Correlates of Entrepreneurship in Three Types of Firms,” Management Science, Vol. 29 No. 7, 1983, pp. 770-791. doi:10.1287/mnsc.29.7.770
[29] W. B. Gartner, “'Who Is an Entrepreneur?’ Is the Wrong Question,” American Journal of Small Business, Vol. 12, No. 4, 1988, pp. 11-32.

[30] W. D. Guth and A. Ginsberg, "Guest Editors: Introduction: Corporate Entrepreneurship,” Strategic Management Journal, Vol. 11, No. 1, 1990, pp. 5-15.

[31] J. G. Covin and D. P. Slevin, "A Conceptual Model of Entrepreneurship as Firm Behavior,” Entrepreneurship Theory and Practice, Vol. 16, No. 1, 1991, pp. 7-25.

[32] S. A. Zahra, "Environment, Corporate Entrepreneurship and Firm Performance. A Taxonomic Approach,” Journal of Business Venturing, Vol. 8, No. 4, 1993, pp. 319-340. doi:10.1016/0883-9026(93)90003-N

[33] H. Barrett and A. Weinstein, "The Effect of Market Orientation and Organizational Flexibility on Corporate Entrepreneurship," Entrepreneurship Theory and Practice, Vol. 23, No. 1, 1998, pp. 57-67.

[34] C. J. Goosen, T. J. De Coning and E. V. D. M. Smit, "Corporate Entrepreneurship and Financial Performance: The Role of Management," South African Journal of Business Management, Vol. 33, No. 4, 2002, pp. 21-27.

[35] D. Henry, “Agency Costs, Corporate Governance and Ownership Structure: Evidence from Australia,” La Trobe University, Melbourne, 2010, pp. 1-44.

[36] B. Aktan and C. Bulut, "Financial Performance Impacts of Corporate Entrepreneurship in Emerging Markets: A Case of Turkey," European Journal of Economics, Finance and Administrative Sciences, Vol. 12, 2008, pp. 69-79.

[37] S. Claessens, S. Djankov, J. Fan and L. H. P. Lang, "Disentangling the Incentive and Entrenchment Effects of Large Shareholdings,” Journal of Finance, Vol. 57, No. 6, 2002, pp. 2741-2772. doi:10.1111/1540-6261.00511

[38] M. L. Lemmon and K. V. Lins, "Ownership Structure, Corporate Governance, and Firm Value: Evidence from the East Asian Financial Crisis,” Journal of Finance, Vol. 58, No. 4, 2003, pp. 1445-1468. doi:10.1111/1540-6261.00573

[39] B. Baysinger and R. E. Hoskisson, "The Composition of Boards of Directors and Strategic Control: Effects on Corporate Strategy," Academy of Management Review, Vol. 15, No. 1, 1990, pp. 72-87.

[40] C. Krishnamurti, K. Udayasankar and S. S. Das, "When Is Two Really Company? The Effects of Competition and Regulation on Corporate Governance,” 2008, pp. 1-57. 